\title{
Alas Kandung-based science learning tools to optimize students' critical thinking skills
}

\author{
Novita Ratnasari a,1, , S. Sarwanto a,2, Baskoro Adi Prayitno a,3 \\ a Master of Science Education Study Program, Faculty of Teacher Training and Education, Universitas Sebelas Maret JI. Ir. Sutami \\ No. 36A Kentingan Surakarta, Central Java 57126 Indonesia \\ ${ }^{1}$ nrsari19@student.uns.ac.id", ${ }^{*}$ sarwanto@fkip.uns.ac.id; ${ }^{3}$ baskoro_ap@fkip.uns.ac.id \\ * Corresponding author
}

\begin{tabular}{|c|c|}
\hline ARTICLE INFO & ABSTRACT \\
\hline $\begin{array}{l}\text { Article history } \\
\text { Received May 05, } 2020 \\
\text { Revised June 06, } 2020 \\
\text { Accepted June 17, } 2020 \\
\text { Published July 21, } 2020 \\
\text { Keywords } \\
\text { Critical thinking skills } \\
\text { Environmental-based learning tools }\end{array}$ & $\begin{array}{l}\text { Critical Thinking Skills (CTS) are the crucial skills required by nowadays generation in } \\
\text { dealing with the } 21^{\text {st }} \text { Century challenges. Yet, the researches focused on higher order } \\
\text { thinking skills are still limited. This study aimed to analyze the effect of Alas Kandung- } \\
\text { based science learning tools on students' CTS. The research design was pretest and } \\
\text { post-test with non-equivalent control group. The treatment given in experimental class } \\
\text { was the implementation of Alas Kandung-based science learning tools, while the control } \\
\text { class was taught using common method used by the teachers. The results of this study } \\
\text { indicated that the students' CTS in experimental class was significantly higher than the } \\
\text { control class }[F(1,47)=11.672, p=0.001] \text {. In conclusion, the Alas Kandung-based } \\
\text { science learning tools is effective in improving students' CTS. }\end{array}$ \\
\hline
\end{tabular}

Learning tools

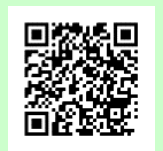

Copyright $\odot 2020$, Ratnasari et al This is an open access article under the CC-BY-SA license

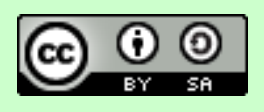

How to cite: Ratnasari, N., Sarwanto, S., \& Prayitno, B. A. (2020). Alas Kandung-based science learning tools to optimize students' critical thinking skills. JPBI (Jurnal Pendidikan Biologi Indonesia), 6(2), 233-242. doi: https://doi.org/10.22219/jpbi. v6i2.12090

\section{INTRODUCTION}

Environmental-based learning is able to train the learners' thinking process, one of them is the skills to think critically (Arti \& Ikhsan, 2020; Irwan. Dewi, Suryadarma, Wilujeng, \& Wahyuningsih, 2017). Learning that based on a student's environment as a learning resource can help achieve the completeness of competence and to help gain experience and knowledge by practicing intellectual skills (Arti \& Ikhsan, 2020; Dwianto, Wilujeng, Prasetyo, \& Suryadarma, 2017; Sasmitatias \& Kuswanto, 2018). The 21st century requires the quality of Human Resources (HR) and the 21st era skills challenges, according to Reeve (2016) and Qin, J., Liu \& Grosvenor (2016) including life and work skills, skills in technology, information communication media, critical thinking skills and creativity. These skills can be trained and elevated through formal and informal learning. The ability development of students in the process of learning science takes precedence in this era rather than relying on the provision of products such as materials, things and concepts (Facione, 2020).

Students' critical thinking skills in Indonesia still need to be improved. The results of the Program for International Student Assessment (PISA) tests in 2018 showed that the average PISA score of Indonesian students was 396 on science, so that Indonesia was ranked 72 out of 77 countries (OECD, 2019).The results of pilot studies of critical thinking skills pattern on chapter interaction of living things with the environment in MTs PSM Tanen Rejotangan (Indonesia) were still low. The $75 \%$ of students were placed in the "very less" category 
$(\mathrm{VL})$ and $25 \%$ of students were placed in "less" category $(\mathrm{L})$ in critical thinking skills pattern. In each indicator of critical thinking skills, analysis of students' answers showed that indicators of interpretation, analysis, evaluation, and self-reinforcement had "very poor" category (VP), as well as conclusion and explanation indicators that have had "less" category (L). Observation of the implementation of learning at the classroom showed that most students were not interested and tended to be passive during the learning process. In addition, there is an Alas Kandung near the MTs PSM Tanen Rejotangan (Indonesia) as the result of environmental observations with a distance around 2.3 kilometers from the school (Ratnasari, Sarwanto, \& Prayitno, 2020). Alas Kandung located in Tanen Village, Rejotangan subdistrict, Tulungagung Regency, East Java province with an area of $\pm 7.4 \mathrm{ha}$, and is at an altitude of $\pm 221 \mathrm{mdpl}$. Alas Kandung location is close to resident settlements and easy to reach. Alas kandung have many species of flora consist of Tectona grandis, Acacia Mangium, Alstonia scholaris, Albizia chinensis, Swietenia macrophylla, Syzygium aqueum, Salacca Zalacca, Zea Mays, Pennisetum purpurium, etc. Moreover, the species of fauna can find in Alas kandung such as Pyramidellidae, Apis indica, Rasbora Argyrotaenia, Oreochromis niloticus, Bronchocela jubata, Lonchura leucogastroides, Pycnonotus aurigaster, Coturnix sp, Lanius Schach.

Critical thinking is the process of evaluating from various points of view with the aim of determining the steps or decisions to be made to create the solution (Facione, 2020). Students' thinking skills can be fostered with critical thoughts (Vong \& Kaewurai, 2017). Critical thinking means thinking deeply, right on target, and involving facts (Ennis, 2011). Furthermore, Facione (2020) says that ideal critical thinkers are able to solve problems wisely. Critical thinking has become one of the goals of education learning outcome in Indonesia (Kemdikbud, 2018). Al-Mubaid et al (2016) proposes that critical thinking must be developed as early as possible so students are able to overcome the global challenges that exist in their environment. In addition, indicators of the quality of Human Resources (HR) are certain to have critical abilities in thinking in this century (Gultepe, 2016; Husamah et al., 2018). Individuals with critical thinking have superior competitiveness in the working environment.

Meaningful learning can elevate students to think critically (Sumarni \& Kadarwati, 2020). The experience can be found by evaluating the accurate information, analyzing problems, conducting experiments, discussing problem solving, working together, and making responsible decisions (Birren \& Kieboom, 2017; Changwong et al., 2018). In conducting experiments, students will learn properly if they use objects and phenomena that occur around them (Wen et al., 2020).

Natural objects that exist around students have the potential as a source of learning that plays a role in elevating critical thinking skills. Involving nature in the learning process means maximizing the potential of the environment as a source of knowledge, as well as building broad and sharp insights into thinking (Dwianto et al., 2017; Susiloningtyas et al., 2017). Nature as a learning reference enables students to more easily associate knowledge (Dewi, Poedjiastoeti, \& Prahani, 2017). Learning is not boring and more meaningful because it is located in an open environment so the students activate all the senses to carry out activities with various objects around them (Susiloningtyas et al., 2016).

One meaningful learning model that can be applied to junior high school students (SMP / MTs) is inquiry learning model. Inquiry can be taught through formal education in schools, one of the type of inquiry model learning is in science learning. Science learning is currently focused on exploration activities to activate students. In conducting exploration, students can utilize Alas Kandung as a learning resource. Otherwise, the advantages are located near the school (MTs PSM Tanen Rejotangan) and ecosystem in Alas Kandung also support the basic competencies about the interaction between living things and the environment (Ratnasari, 2020). The process of analyzing and evaluating that is doing in Alas Kandung, able to improve the meaningfulness of learning so that training the critical thinking skills of students. Students as learners learn to organize and build opinions, formulate problems, develop hypotheses, and find evidence. The process spurs and facilitates students' problem solving abilities that facilitate the learning process of science concepts (Ruvalcaba-Romero, Fernández-Berrocal, Salazar-Estrada, \& Gallegos-Guajardo, 2017). Inquiry learning emphasizes students to construct their knowledge together in experimental groups as well as researchers (Hairida, 2016). Chu et al. (2017) said that inquiry learning that is appropriate to be applied to high school students is guided inquiry. Guided inquiry is deductive inquiry in which problems in the learning process are given by the teacher. Then, students take the decision to solve the problem that has been given (Llewellyn, 2013). The studies related to the using of Alas Kandung as a source of learning are still lack and need more observation, so this research is important to conduct as the basic research to develop the Alas Kandung as a learning source. This research focuses on the use of Alas Kandung as a source of learning to stimulate critical thinking through guided inquiry learning. In the future, this research could be as a reference for further study to make source of learning related to the environment topic. 


\section{METHOD}

The purpose of this study was to examine the effectiveness of Alas Kandung-based science learning tools to optimize students' critical thinking skills. Effectiveness test of developed product was conducted using Pretest and Post-test Nonequivalent Control Group Design with control and experiment classes (McKenney \& Reeves, 2014). Population in this study was all of students in VII class of MTs PSM Tanen Rejotangan Tulungagung, Indonesia in second semester of academic year 2019/2020. The research samples were selected by purposive random sampling. Random sampling technique was chosen because the population was homogeneous and each member of the population had the same opportunity to be selected as objects of this study. Simple random sampling could be done by lottery method. One selected class was used as a control class and one other class was positioned as experimental class. The control class consisted of 24 students while the experimental class consisted of 26 students. The control class was treated by teaching and learning process using conventional method (lecture method) and textbooks as usual. Whereas the experimental class was treated by implementing a guided inquiry learning tools with Alas Kandung as learning resources to improve critical thinking skills that had previously been developed and each class has 5 meetings.

The research instrument consisted of 7 essay questions adapted from each aspect of Facione theory about critical thinking skills, namely: (1) interpretation, (2) analysis, (3) evaluation, (4) explanation, (5) conclusion, and (6) self-reinforcement (Facione, 2020). The score categories of students' critical thinking skills showed in Table 1. The instruments used in this study were tested for validity and reliability by 31 students.

Table 1. Score category of students' critical thinking skills

\begin{tabular}{cc}
\hline Score Range & Category \\
\hline $81.25-100.00$ & Very high \\
$62.50-81.25$ & High \\
$43.75-62.50$ & Medium \\
$25.00-43.75$ & Low \\
$<25.00$ & Very low \\
\hline
\end{tabular}

The data analysis used ANCOVA with the pretest score as the covariate. This analysis using a significance level 0.05 and preceded a prerequisite test, i.e. Shapiro-Wilk normality test and Levene's homogeneity test. The statistical analysis program used SPSS 22 for windows. N-gain was used to determine the effectiveness of the product developed to improve the ability to think critically after the guided inquiry learning process with learning resources applied. The n-gain category is shown in Table 2.

Table 2. Score category of n-gain

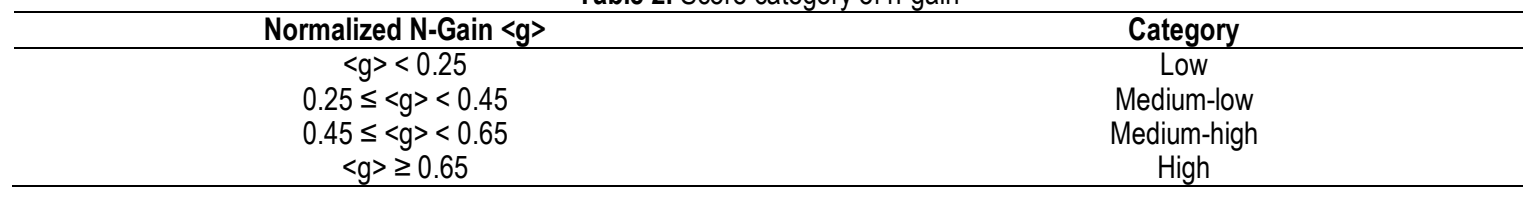

\section{RESULTS AND DISCUSSION}

\section{First Stage: Define}

The results of the analysis showed that the level of students' critical thinking skills had varied in 2 categories mostly, which were: low (L) and very low (VL) as shown in Figure 1.

Based on Figure 1, it is known that $75 \%$ of students have held very low (VL) category of critical thinking skills and $25 \%$ of students have held low category $(L)$ of critical thinking skills. Consequently, in more detail, four out of the six indicators of critical thinking that were also very low (VL) category $(<25.00)$. There are four indicators included: (1) interpretation, (2) analysis, (3) evaluation, and (4) self-reinforcement. Meanwhile, others indicators were categorized in low (L) category under the score 25.00 - 43.75, namely: (1) conclusion and (2) explanation. These results indicated that the learning process carried out so far had not been able to improve students' critical thinking skills. Thus, significant efforts are needed to be able to help improve critical thinking skills. Students' critical thinking skills needs to be improved because it is very fundamental in managing learning skills and empowering students to contribute actively and creatively in life. Students who have good and elevated critical thinking skills are easier to solve problems in their lives. The critical thinking skills is able to explain the causal relationships of events that occur around them (Metcalf et al., 2018). At this stage, an analysis concept of interaction between living things and the environment is carried out on the science basic competencies of junior high school toward Alas Kandung ecosystem. 


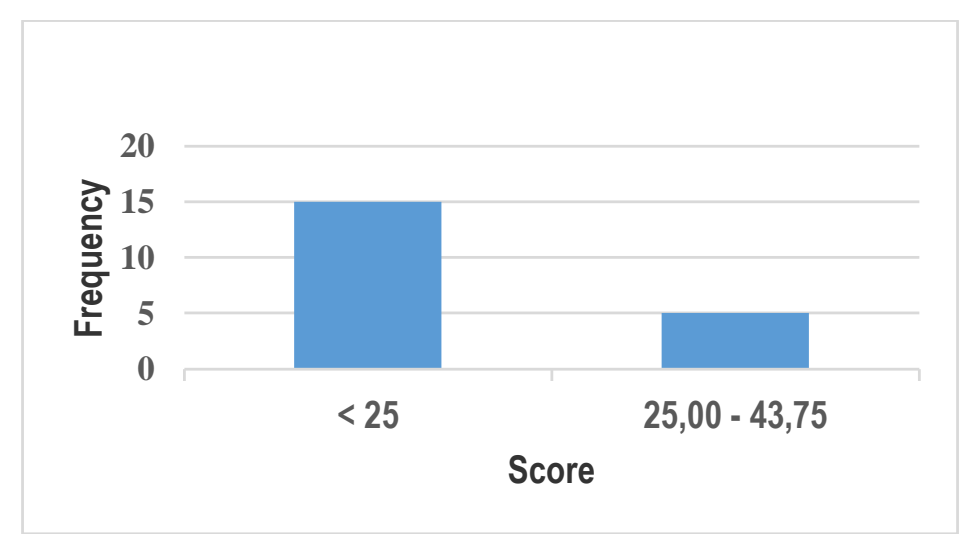

Figure 1. Score achievement analysis of critical thinking skills test

\section{Second Stage: Design}

The results of the analysis at the preliminary study stage (define) were used as a reference in designing learning tools. The reference created the learning tools to develop and have characteristics. There were 6 main characteristics, namely: (1) improving critical thinking skills, (2) concrete problem-based, (3) containing environmental content as a learning resource, (4) student-centered, (5) guided inquiry learning, and (6) using assessment authentic. Besides, adjusting to the results of the preliminary study was done and the six characteristics were also adjusted to the 2013 curriculum so the products (learning tools) could be more easily implemented at the level of junior high schools (SMP / MTs) in Indonesia. Students were conditioned to be able to interact with learning materials actively and carry out various learning activities and get feedback about what they are learning (Makar, Ali, \& Fry, 2018). Design phase produced the first draft of product.

\section{Third Stage: Develop}

\section{The results of content validity}

This stage was used to determine the feasibility of products that have been developed. The learning tools prototype testing phase was carried out by involving several expert as validator (language, media, material, and learning expert validator, and educational practitioners). The results of the validation of the learning kit indicated that the guided inquiry-based product with the Alas Kandung as the learning resources was suitable for use in learning with several revisions shown in Table 3. This stage produces the second draft of product.

Table 3. Validation results of learning tools prototype

\begin{tabular}{ccc}
\hline Validator & Percentage (\%) & Category \\
\hline Language & 92.85 & Very valid \\
Media & 96.66 & Very valid \\
Material & 96.87 & Very valid \\
Learning & 78.00 & Valid \\
Educational practitioners & 98.86 & Very valid \\
\hline Mean of all aspects & 92.64 & Very valid \\
\hline
\end{tabular}

The results on limited testing trial

Science teachers as practitioners and respective users of learning tools developed in this study had responded to products through questionnaires that had been given after usage. Table 4 shows the response of the science teacher to the learning tools that had been designed in the previous stage.

Table 4. Results analysis of teachers questionnaires

\begin{tabular}{ccc}
\hline Aspect & Percentage (\%) & Category \\
\hline Interface & 91.66 & Very valid \\
Content & 91.66 & Very valid \\
Language & 91.66 & Very valid \\
Media & 100.00 & Very valid \\
Learning resource & 100.00 & Very valid \\
\hline Mean of all aspects & 95.00 & Very valid \\
\hline
\end{tabular}


Student responses could be seen from the implementation of learning using learning tools that have been developed. The results of the students' learning outcomes are shown in Table 5. This stage produces the third draft of product that will later be considered to revision after using.

Table 5. The implementation of limited testing trial

\begin{tabular}{cc}
\hline Implementation & Percentage (\%) \\
\hline First meeting & 81.28 \\
First meeting (recurrence) & 93.78 \\
Second meeting & 89.37 \\
Third meeting & 91.33 \\
\hline
\end{tabular}

The results on operational testing

The response of students at this stage could also be seen from the implementation of learning using learning tools that have been developed. The results of the students' learning outcomes are shown in Table 6 .

Table 6. The implementation of operational testing

\begin{tabular}{cc}
\hline Implementation & Percentage (\%) \\
\hline First meeting & 93.70 \\
Second meeting & 99.50 \\
Third meeting & 99.50 \\
\hline
\end{tabular}

This stage had led to the results of fourth draft of product or a guided inquiry learning tools with a learning resource that was properly suitable for implementation in classroom learning and its effectiveness was measured.

\section{Fourth Stage: Disseminate}

The effectiveness of science learning tools based on guided inquiry learning with the Alas Kandung as learning resources was determined in disseminate stage. It was analyzed and stride under the effectiveness analysis indicators. Moreover, the results of the preliminary test using the normality and homogeneity tests in the experimental class and the control class indicate that the data are spread normally and homogeneously. Based on Table 7, it can be concluded that the normality test using the Shapiro-Wilk test showed that the pretest and posttest were normally distribute $(\alpha>0.05)$, while the Levene's homogeneity test in all classes showed homogeneous pretest and posttest because of the significance level $(\alpha>0.05)$.

Table 7. Recapitulation of the results of the normality and homogeneity test

\begin{tabular}{cccc}
\hline Class & Test & Type of test & Result \\
\hline Exp. & Norm. & Shapiro-Wilk test & Sig. pretest 0.288; Sig. posttest 0.141 \\
Ctrl. & Norm. & Shapiro-Wilk test & Sig. pretest 0.442; Sig. posttest 0.696 \\
All Class & Homogeneity & Levene's test & Sig. pretest 0.962; Sig. posttest 0.886 \\
\hline
\end{tabular}

The next test conducted is the ANCOVA to determine the difference in post-test values in the experimental class and the control class. Based on Table 8, there is a significant difference between the post-test value between the experimental class and the control class $(\alpha<0.05)$. Other research done by Nisa et al., (2018) revealed that static fluid learning with guided inquiry model is effective in improving critical thinking skills. Irwan et al., (2019) also found that learning with guided inquiry syntax on ecosystem material is properly linked to critical thinking indicators and it is suitable for use in the learning process. Findings from Nopiya and Fitri (2020) research showed that guided inquiry is able to improve students' interpersonal intelligence. The learning that was carried out did indeed include the component of the scientific method that was able to support the ability to think but had not utilized the natural phenomena that was often encountered by the students in his/her neighborhood. The learning process that utilizes nature around students will present concrete problems and real experiences for students to build sharp thinking and applicable scientific insights. (Muharom Albantani \& Madkur, 2018). Science learning integrated with the local potential of wood carving and pottery was able to influence the critical thinking skills of junior high school students in VIII class (Dewi et al., 2017). The research and development carried out is aimed at improving students' critical thinking skills through meaningful learning by utilizing the natural environment around students as learning resources. Alas Kandung was chosen because of its location that has accessible contact and close to students, easy to reach, and not yet used by other researchers as a source of formal knowledge. Moreover, improving critical thinking skills in the learning process helps students improve their learning outcomes in the classroom (Pratono, Sumarti, \& Wijayati, 2018). Integrating place-based education in biology learning through inquiry can improve the students' cognitive ability in so many different level (Ashari, Pujiank, Ibrohim, Suwono, \& Lukiati, 2018). 
Table 8. ANCOVA test result

\begin{tabular}{llllll}
\hline Source & Sum of Squares & df & Mean Square & F & Sig. \\
\hline Corrected Model & $3620.934^{\mathrm{a}}$ & 2 & 1810.467 & 5.892 & .005 \\
Intercept & 13126.089 & 1 & 13126.089 & 42.720 & .000 \\
Pretest & .410 & 1 & .410 & .001 & .971 \\
Group & 3586.206 & 1 & 3586.206 & 11.672 & .001 \\
Error & 14441.002 & 47 & 307.255 & & \\
Total & 182968.735 & 50 & & & \\
Corrected Total & 18061.936 & 49 & & & \\
\hline
\end{tabular}

a. R Squared $=, 200$ (Adjusted R Squared $=, 166$ )

Table 8 shows that there were significant differences in the critical thinking skills pattern or gap of students whose learning used science learning tools utilizing Alas Kandung as learning resources through guided inquiry (experimental groups) with the comparison of different treatment in students taught using conventional learning resources (control groups). The effectiveness of increasing critical thinking skills in students was shown in Table 9.

Table 9. N-gain students' critical thinking skills score of pretest and post-test

\begin{tabular}{ccc}
\hline Groups & $\mathrm{N}$-gain & Category \\
\hline Exp. & 0.47 & Medium-high \\
Ctrl. & 0.19 & Low \\
\hline
\end{tabular}

The effectiveness of students' improvement of the critical thinking skills score of the experimental group was confirmed not to be lower than the control group. It happened because students became more accustomed to working critically and without difficulty to probing and solving the problems given with stages: formulating problems; expressing an opinion; compiling new knowledge; and deciding on an action based on the problems given. The perspectives in detail from each indicator of critical thinking according to Facione (2020) due to the $\mathrm{N}$-gain scores of the two groups are shown in Table 10.

Table 10. N-gain score on each indicator to students' critical thinking skills

\begin{tabular}{ccccc}
\hline Indicator & \multicolumn{4}{c}{$\mathbf{N}$-gain } \\
\cline { 2 - 5 } & Experimental & Category & Control & Category \\
\hline Interpretation & 0.49 & Medium-high & 0.10 & Low \\
Analysis & 0.53 & Medium-high & 0.25 & Medium-low \\
Evaluation & 0.52 & Medium-high & 0.29 & Medium-low \\
Conclusion & 0.52 & Medium-high & 0.23 & Low \\
Explanation & 0.44 & Medium-low & 0.19 & Low \\
Self-regulation & 0.43 & Medium-low & 0.22 & Low \\
\hline
\end{tabular}

The experimental group had the upper medium dominant $\mathrm{N}$-gain score, while the control group was dominated by the low N-gain score. From Table 8 to Table 10, we could interpret that the level of students' improvement of mean value before and after treatment in two groups of students was different. Thus it can be said that learning interaction of living beings and the environment utilizing the Alas Kandung as learning resources through guided inquiry has a medium increasing effect on critical thinking skills of students of the experimental group.

The obtained improvement of the students' critical thinking skills score utilizing Alas Kandung as learning resources through guided inquiry with an increased level of medium categories above was supported with the findings of Pratono et al. (2018) and Wenning (2011). The findings showed that students were able to grow their skills and build their own knowledge so that their critical thinking skills had also developed. Guided inquiry learning model was able to train active learners independently and collaborate in solving and probing problems provided by the facilitator through investigations (Tindangen, 2018; Uswatun \& Widiyanto, 2018; Zhang, 2019) It was not only increasing the ability of students to understand the material, but it can also improve the process skills and scientific work (Hunaepi et al., 2019; Khasanah \& Widoretno, 2017; Mutakinati et al., 2018; Putra et al., 2016). Stages in the investigation of learning models from stage to stage to formulate the problem until the conclusion were proven to guide students in making the concept of accommodation and assimilation as Piaget theory (Slavin, 1994).

Learning by inquiry methods can utilize alternative learning resources such as the environment around students. Nature as a provider of needs from all aspects of life is an effective media to stimulate thinking skills and develop one's knowledge because by utilizing nature, students will be motivated to discover new things, which will then become an assimilation of knowledge (Arti \& Ikhsan, 2020; Muharom Albantani \& Madkur, 2018; Rogers, 1995). 
According to Ardan (2016) social interaction obtained in groups and between groups during the learning process with guided inquiry model can increase the potential of students to collaborate (Ardan, 2016). Collaboration is also one of the skills that must be possessed in this era. Students who were actively involved independently or collaborate in inquiry-based learning were easier to have information in long-term memory, so mastery of the concepts increased well and elevated properly (Irwan et al., 2019; Slavin, 1994). Learning outcomes through inquiry models can improve understanding of science, increase learning objectives and trigger the use of critical thinking skills (Prasetyowati \& Suyatno, 2016; Sulistijo et al., 2017), improve predictive skills, and elevate mastery of concepts. Nevertheless, there was a significant correlation between critical thinking skills and students' mastery concepts (Prasetyowati \& Suyatno, 2016). Pursitasari et al. (2020) and Ramdiah et al. (2019) also agreed that guided inquiry-based learning by utilizing the environment around students effectively made students critical thinkers, which this ability is a provision for real life in the future and near globalization.

The implications of this research and development can be used as a theoretical basis and fundamental in subsequent studies related to learning science. Also, these finding can lead to the implemented teaching and learning process by science teachers in learning the material interaction of living things and the environment within natural learning resources. This learning tools can also be used as an example for science teachers to develop learning tools based on guided inquiry based on other material.

\section{CONCLUSION}

The treatment given to students was science learning process with the combination of developed science learning tools and Alas Kandung as learning resources. Students in the two groups were given the same test (pretest and post-test). The results of this study indicated that there is a significant difference between the posttest scores of students' critical thinking skills in each group with significance value $=0.001$. Furthermore, the average n-gain critical thinking of the experimental group students was higher. The conclusion of this research was developed science learning tools with Alas Kandung as learning resources through guided inquiry was effectively enhancing and improving students' thinking pattern as critical thinking learners.

\section{ACKNOWLEDGEMENT}

The researcher would like to thank the Universitas Sebelas Maret for constructive criticism and useful suggestions during the study.

\section{REFERENCES}

Al-Mubaid, H., Abukmail, A., \& Bettayeb, S. (2016). Empowering deep thinking to support critical thinking in teaching and learning. In SIGMIS-CPR 2016 - Proceedings of the 2016 ACM SIGMIS Conference on Computers and People Research (pp. 69-75). doi: https://doi.org/10.1145/2890602.2890606

Ardan, A. S. (2016). The development of biology teaching material based on the local wisdom of timorese to improve students knowledge and attitude of environment in caring the persevation of environment. International Journal of Higher Education, 5(3), 190-200. doi: https://doi.org/10.5430/ijhe.v5n3p190

Arti, Y., \& Ikhsan, J. (2020). The profile of junior high school students' critical thinking skills and concept mastery level in local wisdom based on outdoor learning. Journal of Physics: Conference Series, 1440(1). doi: https://doi.org/10.1088/1742-6596/1440/1/012105

Ashari, A., Pujiank, S., Ibrohim, I., Suwono, H., \& Lukiati, B. (2018). Integrating place-based education in biology learning through inquiry to improve studentrs cognitive ability and scientific attitudes in Sumbawa. Advances in Social Science, Education and Humanities Research, 218(ICoMSE 2017), 151-154. doi: https://doi.org/10.2991/icomse-17.2018.27

Birren, J. M., \& Kieboom, L. A. V. D. (2017). Exploring the development of core teaching practices in the context of inquiry-based science instruction: an interpretive case study. Teaching and Teacher Education, 66, 74-87. doi: https://doi.org/10.1016/j.tate.2017.04.001

Changwong, K., Sukkamart, A., \& Sisan, B. (2018). Critical thinking skill development: Analysis of a new learning management model for Thai high schools. Journal of International Studies, 11(2), 37-48. doi: https://doi.org/10.14254/2071-8330.2018/11-2/3

Chu, S. K. W., Reynolds, R. B., Tavares, N. J., Notari, M., \& Lee, C. W. Y. (2017). 21st century skills 
development through inquiry-based learning. Switzerland: Springer. doi: https://doi.org/10.1007/97898110-2481-8

Dewi, I. N., Poedjiastoeti, S., \& Prahani, B. K. (2017). ELSII learning model based local wisdom to improve students' problem solving skills and scientific communication. International Journal of Education and Research, 5(1), 107-118. Retrieved from https://www.researchgate.net/profile//ka_Dewi2/publication/ 333772671

Dewi, I. P. M., Suryadarma, I. G. P., Wilujeng, I., \& Wahyuningsih, S. (2017). The effect of science learning integrated with local potential of wood carving and pottery towards the junior high school students' critical thinking skills. Jurnal Pendidikan IPA Indonesia, 6(1), 103-109. doi: https://doi.org/10.15294/jpii. v6i1.9598

Dwianto, A., Wilujeng, I., Prasetyo, Z. K., \& Suryadarma, I. G. P. (2017). The development of science domain based learning media which is integrated with local potention to improve science process skill and scientific attitude. Jurnal Pendidikan IPA Indonesia, 6(1), 23-31. doi: https://doi.org/10.15294/jpii.v6i1. 7205

Ennis, R. H. (2011). The nature of critical thinking : An outline of critical thinking dispositions. University of Illinois. Retrieved from https://education.illinois.edu/docs/default-source/faculty-documents/robert-ennis/ thenatureofcriticalthinking_51711_000.pdf

Facione, P. A. (2020). Advancing thinking worldwide - critical thinking: What it is and why it counts. Journal of Chemical Information and Modeling (Vol. 53). doi: https://doi.org/10.1017/CB09781107415324.004

Gultepe, N. (2016). High school science teachers' views on science process skills. International Journal of Environmental and Science Education, 11(5), 779-800. doi: https://doi.org/10.12973/ijese.2016.348a

Hairida. (2016). The effectiveness using inquiry based natural science module with authentic assessment to improve the critical thinking and inquiry skills of junior high school students. Jurnal Pendidikan IPA Indonesia, 5(2), 209-215. doi: https://doi.org/10.15294/jpii.v5i2.7681

Hunaepi, H., Nuraini, I., \& Sumarjan, S. (2019). Profiling students 'environmental care attitudes taught using sasak tribe local wisdom-integrated model. JPBI (Jurnal Pendidikan Biologi Indonesia), 5(3), 549-558. doi: https://doi.org/ 10.22219/jpbi.v5i3.10009

Husamah, Fatmawati, D., \& Setyawan, D. (2018). OIDDE learning model: Improving higher order thinking skills of biology teacher candidates. International Journal of Instruction, 11(2), 249-264. doi: https://doi.org/10.12973/iji.2018.11217a

Irwan, Maridi, \& Dwiastuti, S. (2019). Developing guided inquiry-based ecosystem module to improve students ' critical thinking skills. JPBI (Jurnal Pendidikan Biologi Indonesia), 5(1), 51-60. doi: https://doi.org/ 10.22219/jpbi.v5i1. 7287

Kemdikbud. Peraturan Menteri Pendidikan dan Kebudayaan Republik Indonesia No. 37 Tahun 2018, Jakarta § (2018). Indonesia. Retrieved from https://jdih.kemdikbud.go.id/arsip/Permendikbud Nomor 37 Tahun 2018.pdf

Khasanah, A. N., \& Widoretno, S. (2017). Effectiveness of critical thinking indicator-based module in Eempowering student's learning outcome in respiratory study material. Jurnal Pendidikan IPA Indonesia, 6(1), 187-195. doi: https://doi.org/10.15294/jpii.v6i1.8490

Llewellyn, D. (2013). Inquire within: Implementing inquiry-and argument-based science standards in grades 38. (Douglas Llewellyn, Ed.), Corwin press (3rd ed.). St. John Fisher College, Rochester, New York: corwin. Retrieved from https://us.corwin.com/en-us/nam/inquire-within/book241066

Makar, K., Ali, M., \& Fry, K. (2018). Narrative and inquiry as a basis for a design framework to reconnect mathematics curriculum with students. International Journal of Educational Research, 92, 188-198. doi: https://doi.org/10.1016/j.ijer.2018.09.021

McKenney, S., \& Reeves, T. C. (2014). Educational design research. In Handbook of Research on Educational Communications and Technology (pp. 131-140). New York, NY: Springer New York. doi: https://doi.org/10.1007/978-1-4614-3185-5_11

Metcalf, S. J., Reilly, J. M., Kamarainen, A. M., King, J., Grotzer, T. A., \& Dede, C. (2018). Supports for deeper learning of inquiry-based ecosystem science in virtual environments - Comparing virtual and physical concept mapping. Computers in Human Behavior, 87(10), 459-469. doi: https://doi.org/10. 1016/j.chb.2018.03.018

Muharom Albantani, A., \& Madkur, A. (2018). Think globally , act locally : The strategy of incorporating local wisdom in foreign language teaching in Indonesia. International Journal of Applied Linguistics and English Literature, 7(2), 1. doi: https://doi.org/10.7575/aiac.ijalel.v.7n.2p.1 
Mutakinati, L., Anwari, I., \& Yoshisuke, K. (2018). Analysis of Student's Critical Thinking of Middle School Through STEM Education Project-Based Learning. Jurnal Pendidikan IPA Indonesia, 7(1), 54-65. doi: https://doi.org/10.15294/jpii.v7i1.10495

Nisa, E. K., Koestiari, T., Habibbulloh, M., \& Jatmiko, B. (2018). Effectiveness of guided inquiry learning model to improve students' critical thinking skills at senior high school. Journal of Physics: Conference Series, 997(1). doi: https://doi.org/10.1088/1742-6596/997/1/012049

Nopiya, N., Hindriana, A. F., \& Sulistyono, S. (2020). Students' science process skills and interpersonal intelligence in biology learning using guided inquiry. JPBI (Jurnal Pendidikan Biologi Indonesia), 6(1), 123-134. doi: https://doi.org/10.22219/jpbi.v6i1.10634

OECD. (2019). PISA 2018 insights and interpretations. PISA. OECD Publishing. Paris., 64. Retrieved from https://www.oecd.org/pisa/PISA 2018 Insights and Interpretations FINAL PDF.pdf

Prasetyowati, E. N., \& Suyatno. (2016). Peningkatan penguasaan konsep dan keterampilan berpikir kritis siswa melalui limplementasi model pembelajaran inkuiri pada materi pokok larutan penyangga. Jurnal Kimia Dan Pendidikan Kimia, 1(1), 67-74. doi: https://doi.org/10.20961/jkpk.v1i1.10122

Pratono, A., Sumarti, S. S., \& Wijayati, N. (2018). Contribution of assisted inquiry model of E-module to students science process skill. Journal of Innovative Science Education, 7(25), 62-68. doi: https:/l doi.org/10.15294/jise.v7i1.20633

Pursitasari, I. D., Suhardi, E., Putra, A. P., \& Rachman, I. (2020). Enhancement of student's Critical thinking skill through science context-based inquiry learning. Jurnal Pendidikan IPA Indonesia, 9(1), 97-105. doi: https://doi.org/10.15294/jpii.v9i1.21884

Putra, M. I. S., Widodo, W., \& Jatmiko, B. (2016). The development of guided inquiry science learning materials to improve science literacy skill of prospective MI teachers. Jurnal Pendidikan IPA Indonesia, 5(1), 8393. doi: https://doi.org/10.15294/jpii.v5i1.5794

Qin, J., Liu, Y., \& Grosvenor, R. (2016). A categorical framework of manufacturing for industry 4.0 and beyond. Procedia CIRP, 52, 173-178. doi: https://doi.org/10.1016/j.procir.2016.08.005

Ramdiah, S., Abidinsyah, A., Royani, M., \& Husamah, H. (2019). Understanding, Planning, and Implementation of HOTS by Senior High School Biology Teachers in Banjarmasin-Indonesia. International Journal of Instruction, 12(1), 425-440. doi: https://doi.org/10.29333/iji.2019.12128a

Ratnasari, N. (2020). Pengembangan perangkat pembelajaran interaksi makhluk hidup dan lingkungan dengan sumber belajar alas kandung untuk meningkatkan kemampuan berpikir kritis peserta didik. Universitas Sebelas Maret. doi: https://doi.org/10.17977/jptpp.v3i2.10506

Ratnasari, N., Sarwanto, \& Prayitno, B. A. (2020). The role of students' critical thinking skills in junior high schools on chapter organism and its environment. J. Phys.: Conf. Ser., 1511(012064). doi: https://doi. org/10.1088/1742-6596/1511/1/012064

Reeve, E. (2016). 21st century skills needed by students in technical and vocational education and training (TVET). Asian International Journal of Social Sciences, 16(4), 54-61. doi: https://doi.org/10.29139/aijss. 20160404

Rogers, E. M. (1995). Lessons for guidelines from the diffusion of innovations. The Joint Commission Journal on Quality Improvement, 21(7), 324-328. doi: https://doi.org/10.1016/S1070-3241(16)30155-9

Ruvalcaba-Romero, N. A., Fernández-Berrocal, P., Salazar-Estrada, J. G., \& Gallegos-Guajardo, J. (2017). Positive emotions, self-esteem, interpersonal relationships and social support as mediators between emotional intelligence and life satisfaction. Journal of Behavior, Health \& Social Issues, 9(1), 1-6. doi: https://doi.org/10.1016/j.jbhsi.2017.08.001

Sasmitatias, F., \& Kuswanto, H. (2018). The development of science learning device based on serukam local culture to improve students ' analytical skill. International Journal of Educational Research Review, 3(3), 59-68. doi: https://doi.org/10.24331/ijere.441348

Slavin, R. E. (1994). A practical guide to cooperative learning. (A. and Bacon, Ed.). California: Macmillan College. Retrieved from https://books.google.co.id/books/about/A_Practical_Guide_to_Cooperative LLearnin.html?id=ph8iAQAAIAAJ\&redir_esc=y

Sulistijo, S. H., Sukarmin, S., \& Sunarno, W. (2017). Physics learning using inquiry-student team achievement division (ISTAD) and guided inquiry models viewed by students achievement motivation. Jurnal Pendidikan IPA Indonesia, 6(1), 130-137. doi: https://doi.org/10.15294/jpii.v6i1.9601

Sumarni, W., \& Kadarwati, S. (2020). Ethno-STEM project-based learning: Its impact to Critical and creative thinking skills. Jurnal Pendidikan IPA Indonesia, 9(1), 11-21. doi: https://doi.org/10.15294/jpii.v9i1.21 754

Susiloningtyas, D., Handayani, T., Amalia, N., \& Nadhira, A. I. (2016). Spatial analysis on school environment 
characteristics in mangrove management based on local wisdom (Case study at Lhokseumawe, Aceh). In Journal of Physics: Conference Series (Vol. 755, p. 11001). doi: https://doi.org/10.1088/1742-6596/ $755 / 1 / 011001$

Tindangen, M. (2018). Inquiry-based learning model to improve higher order thinking skills. Asian Social Sciences, 14(7), 39-46. doi: https://doi.org/10.5539/ass.v14n7p39

Uswatun, D. A., \& Widiyanto, R. (2018). Analisis aktivitas peserta didik dalam pembelajaran berbasis scientific approach di sekolah dasar sebagai implementasi 21st century skills. JIPVA (Jurnal Pendidikan IPA Veteran), 2(2), 174-188. doi: https://doi.org/10.31331/jipva.v2i2.680

Vong, S. A., \& Kaewurai, W. (2017). Instructional model development to enhance critical thinking and critical thinking teaching ability of trainee students at regional teaching training centre in Takeo Province, Cambodia. Kasetsart Journal of Social Sciences, 38, 88-95. doi: https://doi.org/10.1016/j.kjss.2016. 05.002

Wei, W., Hudson, M. A., \& Cook, A. E. (2019). Developing students' critical thinking, problem solving, and analysis skills in an inquiry-based synthetic organic laboratory course. In Journal of Chemical Education (Vol. 93, pp. 448-469). ACS Publications. doi: https://doi.org/10.4018/978-1-5225-7823-9.ch022

Wen, C. T., Liu, C. C., Chang, H. Y., Chang, C. J., Chang, M. H., Chiang, S. H., \& Hwang, F. K. (2020). Students' guided inquiry with simulation and its relation to school science achievement and scientific literacy. Computers \& Education, 149, 1-10. doi: https://doi.org/10.1016/j.compedu.2020.103830

Wenning, C. J. (2011). Experimental inquiry in introductory physics courses Carl. Illinois State University Physics Dept., 6(2), 1. Retrieved from http://pantaneto.co.uk/experimental-inquiry-in-introductory-physic s-course-carl-j-wenning/

Zhang, L. (2019). "Hands-on" plus "inquiry"? Effects of withholding answers coupled with physical manipulations on students' learning of energy-related science concepts. Learning and Instruction, 60, 199-205. doi: https://doi.org/10.1016/j.learninstruc.2018.01.001 